\title{
Tracking Soil Erosion Changes in an Easily-Eroded Watershed of the Chinese Loess Plateau
}

\author{
Lei $\mathrm{Wu}^{1,2 *}$, Xia Liu ${ }^{3}$, Xiao-yi Ma ${ }^{1}$ \\ ${ }^{1}$ College of Water Resources and Architectural Engineering, Northwest A\&F University, Yangling, \\ Shaanxi 712100, P.R. China \\ ${ }^{2}$ State Key Laboratory of Soil Erosion and Dryland Farming on the Loess Plateau, Northwest A\&F University, \\ Yangling, Shaanxi 712100, P.R. China \\ ${ }^{3}$ Construction Department, Northwest A\&F University, Yangling, \\ Shaanxi 712100, P.R. China
}

Received: 9 September 2015

Accepted: 4 November 2015

\begin{abstract}
Soil erosion is one of the most important environmental concerns in the hilly and gully region of the Chinese Loess Plateau. In this study, a distributed soil erosion model considering the shallow gully erosion (ephemeral gully erosion) was used to simulate and track soil erosion changes in an easily-eroded watershed from 1985 to 2010. Results indicate that:

1) The distributed soil erosion model based on the RUSLE is suitable for the hilly and gully region of the Loess Plateau and can better improve modeling capabilities for future study of sediment and pollution.

2) The overall soil erosion intensity in the southeast and central parts of the watershed is higher than that of the northwest. The spatiotemporal variations of soil erosion in the whole watershed are largely related to rainfall erosion distribution and land use layout.

3) Effects of returning farmland measures on soil erosion in the Yanhe River upstream are remarkable, and the Panlong River basin needs to further strengthen soil and water conservation measures, and the Yanhe downstream cannot also be ignored in future watershed management planning.

4) Dry land is the critical source area before and after returning farmland in the watershed. The implementation of soil and water conservation measures of dry land is a top priority for soil erosion prevention and control of the watershed. Results may provide scientific reference for erosion identification of critical source areas and land use planning in the loess hilly and gully region.
\end{abstract}

Keywords: soil erosion; spatiotemporal variations; distributed model; returning farmland, Yanhe River watershed

*e-mail: 1wu@nwsuaf.edu.cn 


\section{Introduction}

Soil erosion is one of the important environmental problems endangering the survival and development of people in China [1]. According to the 1990 national census data of remote sensing, the water erosion area in China is $1.79 \times 10^{6} \mathrm{~km}^{2}$ and annual soil loss is up to 50 tons [2]. The Loess Plateau is one of the most serious regions of soil erosion in the world [3]. Serious soil erosion not only exacerbates the deterioration of the ecological environment, but also leads to a large amount of sediment flowing into the Yellow River [4]. The sediment itself is a kind of non-point source pollution and is also the main carrier of various toxic and harmful substances. These pollutants will bring many adverse effects to the receiving water, which may badly threaten the harmonious development of the economy and society in the Loess Plateau [5].

Natural factors causing serious soil erosion in this region mainly include the concentrated precipitation, loose soil, fragmented topography, and the degraded vegetation ecosystem [6]; irrational land use layout related to human activities is also an important reason for intensified soil erosion [7, 8]. The Yanhe River is a first-grade tributary of the Yellow River, and the Yanhe watershed is one of the most typical easily-eroded regions in the hilly and gully region of the Loess Plateau [9]. Therefore, the tracking study of soil erosion changes before and after returning farmland (Beginning in 1997 [10]) has important significance for revealing the rules of soil erosion in the
Yanhe River watershed, preventing soil degradation, enhancing agricultural production, and reducing sand introduced to the Yellow River.

In general, due to lack of enough measured data, it is very difficult - even impossible - to apply conceptual and physical models in evaluating soil erosion for large-scale watersheds [11-14]. In other words, previous studies have shown that the application scope of WEPP, ANSWERS, and other mechanism models is narrow in China due to parameter problems [15]. Therefore, empirical models are widely used for soil erosion modeling in the world. Among them, the universal soil loss equation (USLE) is one of the typical models in the process of soil erosion simulation studies [16]. Because of its convenience in application and compatibility with geographical information system (GIS), the combined use of the USLE or its revised form (RUSLE) [17], remote sensing, and GIS techniques makes soil erosion estimation and its spatial distribution feasible with reasonable accuracy on a large scale [18], and it has been dominantly used in GIS-based soil erosion assessments of different scales in different countries $[19,20]$. It is not only one of the most widely used empirical models to predict soil erosion at field scales resulting from sheet and rill erosion [21], but also frequently to estimate soil erosion at basin scales resulting from slope erosion [22]. It can estimate spatial heterogeneity of potential erosions and identification of critical erosionprone areas in watersheds [23]. The application effects of this model have been validated in recent studies [24, $25]$.

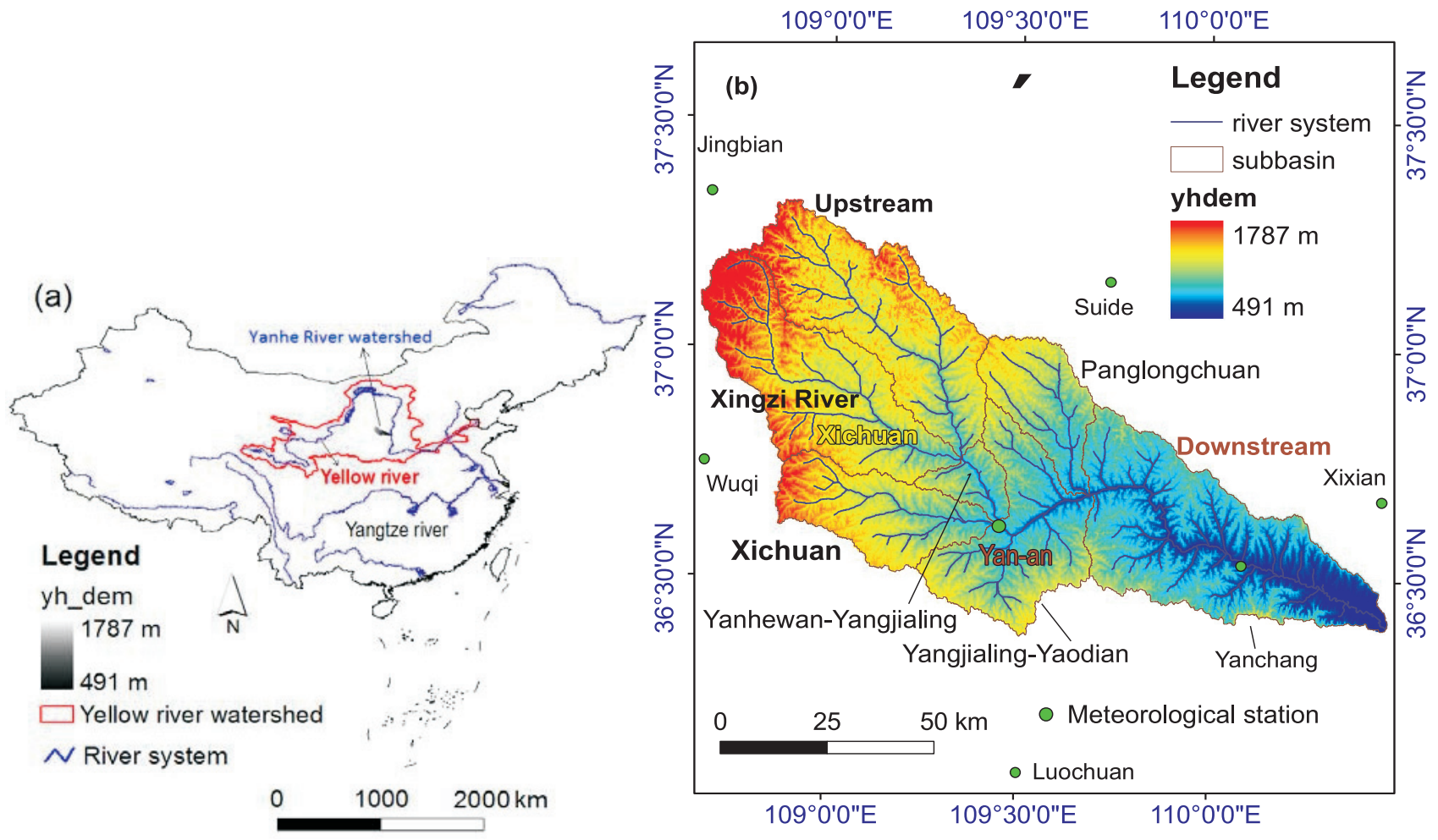

Fig. 1. The study area: (a) the relative location between the study area and the Yellow River/Yellow River Basin in China; (b) longitude and latitude coordinates of the study area, digital elevation model (DEM) data, and the delineation of sub-basin, river systems, and meteorological station within the Yanhe River watershed. 
Table 1. Descriptions and sources of the environmental database for the Yanhe River watershed.

\begin{tabular}{|c|c|c|c|}
\hline Data layer & Format & Description & Source \\
\hline DEM & Raster & $\begin{array}{c}\text { DEM data of the Yanhe River watershed (90 } \\
\text { m) }\end{array}$ & $\begin{array}{c}\text { Computer Network Information Center, Chinese } \\
\text { Academy of Sciences http://datamirror.csdb.cn/ } \\
\text { index.jsp }\end{array}$ \\
\hline Land use & Raster & $\begin{array}{c}\text { Land use classification (GB } \backslash \mathrm{T} 21010-2007) / \\
\text { PRC National Standard (100 m) }\end{array}$ & $\begin{array}{c}\text { Data Center for Cold and Arid Region Sciences } \\
\text { http://westdc.westgis.ac.cn/ }\end{array}$ \\
\hline Soil & DBF & Soil physicochemical properties & $\begin{array}{c}\text { Data Sharing Network of Earth System Science } \\
\text { http://loess.geodata.cn/ }\end{array}$ \\
\hline $\begin{array}{c}\text { Meteorological } \\
\text { data }\end{array}$ & DBF & Daily precipitation (1957-2013) & $\begin{array}{c}\text { China Meteorological Data Sharing Service Network } \\
\text { http://www.cdc.sciencedata.cn }\end{array}$ \\
\hline
\end{tabular}

Because Chinese early empirical model do not consider the specific process of soil erosion and has strong regional pertinence, its practical applicability is apparently lower than that of RUSLE [26]. USLE model and its revised form have also been widely used in China [27], but many studies have shown that the application of RUSLE needs proper corrections according to the watershed conditions and research purposes [28]. As far as the Yanhe River watershed is concerned, under dual effects of complex steep terrain conditions and human activities, the shallow gully erosion has a significant impact on slope erosion and sediment yield [29].
Therefore, it is necessary to consider the effects of shallow gully erosion on soil erosion in the loess hilly and gully region. The objectives of this study are to: 1) establish a distributed soil erosion model containing the shallow gully erosion, 2) simulate spatiotemporal distributions of soil erosion in the Yanhe River watershed, and 3) track soil erosion changes of the Yanhe River watershed in the hilly and gully region. The model proposed here could better improve modeling capabilities for spatiotemporal distribution of soil erosion; the data reported in this paper could also provide a scientific basis for the regional prevention and control of soil erosion in the Loess Plateau.

Table 2. Land use information of the Yanhe River watershed from 1985 to 2010.

\begin{tabular}{|c|c|c|c|c|c|c|c|}
\hline \multirow{2}{*}{$\begin{array}{l}\text { One-level } \\
\text { code }\end{array}$} & \multirow{2}{*}{ Classification } & \multirow{2}{*}{$\begin{array}{l}\text { Two-level } \\
\text { code }\end{array}$} & \multirow{2}{*}{ Land use types } & 1985 & 1995 & 2005 & 2010 \\
\hline & & & & \multicolumn{4}{|c|}{ Percentage } \\
\hline 1 & cultivated land & 12 & dry land & 43.181 & 43.349 & 40.634 & 40.115 \\
\hline \multirow{4}{*}{2} & \multirow{4}{*}{ forestland } & 21 & closed forest land & 0.538 & 0.462 & 0.554 & 0.551 \\
\hline & & 22 & shrub land & 6.903 & 6.618 & 7.364 & 7.372 \\
\hline & & 23 & sparse wood land & 2.951 & 3.071 & 3.129 & 3.139 \\
\hline & & 24 & other forest land & 0.320 & 0.360 & 2.858 & 3.046 \\
\hline \multirow{3}{*}{3} & \multirow{3}{*}{ grassland } & 31 & high coverage grassland & 0.072 & 0.025 & 0.476 & 0.476 \\
\hline & & 32 & middle coverage grassland & 21.656 & 17.267 & 21.048 & 21.151 \\
\hline & & 33 & low coverage grassland & 23.684 & 28.093 & 23.210 & 23.384 \\
\hline \multirow{4}{*}{4} & \multirow{4}{*}{ water area } & 41 & river and canals & 0.197 & 0.194 & 0.194 & 0.199 \\
\hline & & 42 & lake & 0.001 & 0.004 & 0.001 & 0.016 \\
\hline & & 43 & reservoir and pond & 0.091 & 0.105 & 0.033 & 0.030 \\
\hline & & 46 & bottomland & 0.067 & 0.059 & 0.055 & 0.056 \\
\hline \multirow{3}{*}{5} & \multirow{3}{*}{$\begin{array}{l}\text { urban, industry } \\
\text { and mining, rural } \\
\text { residents land }\end{array}$} & 51 & urban & 0.060 & 0.067 & 0.107 & 0.108 \\
\hline & & 52 & rural residential area & 0.224 & 0.262 & 0.273 & 0.278 \\
\hline & & 53 & $\begin{array}{l}\text { industrial and traffic } \\
\text { construction land }\end{array}$ & 0.024 & 0.029 & 0.031 & 0.044 \\
\hline 6 & unused land & 65 & bare ground & 0.032 & 0.035 & 0.034 & 0.034 \\
\hline
\end{tabular}

Note: Three-level classification of dry land (code 12) in Figure 3: code 121 (Mountainous dry land); code 122 (Hilly dry land); code 123 (Plain dry land); code 124 ( $>25^{\circ}$ sloping dry land). 


\section{Material and Methods}

\section{Study Area}

The Yanhe River, which originates from the Baiyu Mountain of Jingbian County, is one of the main tributaries of the Yellow River (Fig. 1a). It flows through five counties (districts), including Jing-bian, Zhi-dan, Ansai, Baota, and Yangchang from northwest to southeast in Shaanxi Province $\left(108^{\circ} 38^{\prime} \sim 110^{\circ} 29^{\prime} \mathrm{E}, 36^{\circ} 21^{\prime} \sim 37^{\circ} 19^{\prime} \mathrm{N}\right)$, and finally it empties into the Yellow River in Nanhe ditch, Yan-chang County (Fig. 1b). The Yanhe catchment area is $7,725 \mathrm{~km}^{2}$, and it mainly includes tributaries of the Xingzi, Xi-chuan, Panlong-chuan, and Nan-chuan rivers, with average annual precipitation of about $495.6 \mathrm{~mm}$ and almost $60 \%$ of the total annual rainfall occurring during the monsoon period (June-September). The most widely distributed soil in the watershed is alluvial soil.

\section{Environmental Database}

The environmental parameters in the study mainly include digital elevation (DEM), land use, precipitation, and soil properties (Tables 1 and 2). In this study, the Yanhe watershed is divided into seven sub basins as shown in Fig. $1 b$.

\section{Methodology}

In general, the topography and soil characteristics in a watershed are basically invariant in a relatively short period of time. Dynamic variations of soil erosion predominately arise from rainfall conditions [30] and vegetation cover management measures [31]. Therefore, factors of $K, L, S$, and $P$ in the RUSLE equation can be assumed to be constants because they reflect topography and soil characteristics, but $R$ and $C$ factors will change year by year with rainfall conditions and vegetation cover management measures. Besides, shallow gully erosion is one of the main methods of soil erosion in the middle and lower part of the sloping land, and plays an especially important role in the slope soil erosion of Chinese loess plateau [32], so the shallow gully erosion was introduced to accurately estimate soil erosion of the Yanhe watershed in this study. Thus, the RUSLE equation can be changed into the simple annual soil erosion model:

$$
E_{i}=R_{i} \cdot K \cdot L S \cdot G \cdot C_{i} \cdot P
$$

...where $E$ is the annual average soil erosion modulus over many years, $\mathrm{t} /(\mathrm{ha} \cdot \mathrm{a}) ; R$ is the rainfall erosivity factor, $\mathrm{MJ} \cdot$ $\mathrm{mm} /(\mathrm{ha} \cdot \mathrm{h} \cdot \mathrm{a}) ; K$ is the soil erodibility factor, $\mathrm{t} \cdot \mathrm{ha} \cdot \mathrm{h} /(\mathrm{ha} \cdot$ $\mathrm{MJ} \cdot \mathrm{mm}) ; L S$ is the slope length and slope gradient factor; $\mathrm{G}$ is the shallow gully erosion factor; $C$ is the vegetation cover and management factor; and $P$ is the soil and water conservation factor. $L S, G, C$ and $P$ are dimensionless; the subscript i represents the i-th year.

1) Rainfall erosivity factor

The half-month method shows the seasonal distribution of rainfall erosivity by the period of half month, and has been widely used in China [33]. In this study, a half-month simple algorithm of rainfall erosivity established by Zhang et al. [34] was used to calculate rainfall erosivity. The halfmonth algorithm of rainfall erosivity estimated by daily rainfall is as follows:

$$
R_{i}=\alpha \sum_{j=1}^{k}\left(P_{j}\right)^{\beta}
$$

...where $R_{i}$ represents the rainfall erosivity value in $i$-th half-month period $\left(\mathrm{MJ} \cdot \mathrm{mm} \cdot \mathrm{hm}^{-2} \mathrm{~h}^{-1}\right), k$ represents the number of days within the half-month period, $P_{\mathrm{j}}$ is rainfall in the $j$-th day during the half-month period, and the requirement of daily rainfall is greater than or equal to $12 \mathrm{~mm}$ (erosive rainfall standard).
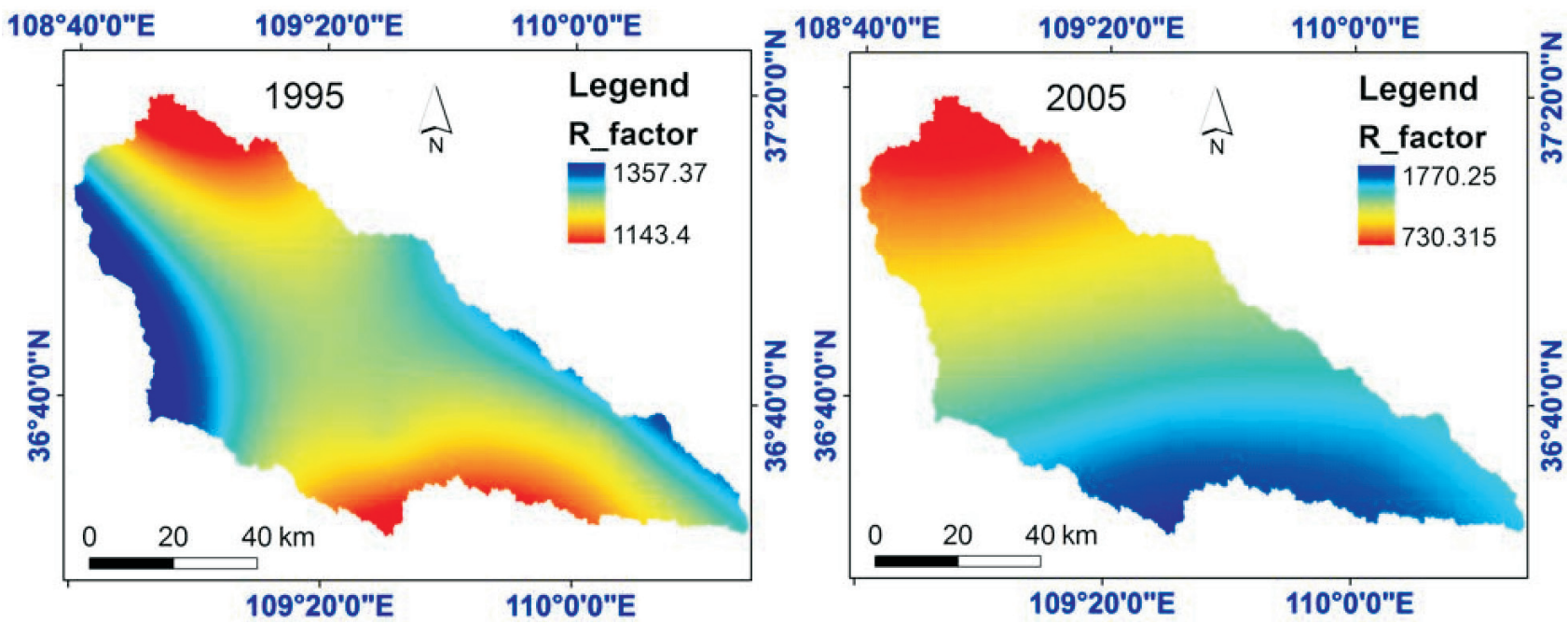

Fig. 2. Rainfall erosivity factor of the Yanhe River watershed from 1985 to 2010. 
Table 3. K value of different soil types in the Yanhe River watershed [39].

\begin{tabular}{|c|c|c|c|c|c|}
\hline Soil types & K value & Percentage of area/\% & Soil types & K value & Percentage of area/\% \\
\hline Loessal soil & 0.01765 & 97.77 & Clay Heilu soil & 0.02277 & 0.09 \\
\hline Alluvial soils & 0.03205 & 1.76 & Calcareous skeletal soil & 0.0292 & 0.02 \\
\hline Red clay soil & 0.03224 & 0.29 & Skeletal soil & 0.0292 & 0.05 \\
\hline
\end{tabular}

$$
\begin{gathered}
\beta=0.8363+\frac{18.144}{P_{d_{12}}}+\frac{24.455}{P_{y_{12}}} \\
\alpha=21.586 \beta^{-7.1891}
\end{gathered}
$$

... where $P_{\mathrm{d} 12}$ represents the average daily rainfall when the daily rainfall is greater than $12 \mathrm{~mm}$, and $P_{\mathrm{y} 12}$ represents the average annual rainfall when the daily rainfall is greater than $12 \mathrm{~mm}$. The rainfall erosivity factor of the Yanhe watershed was estimated and spatially showed in Fig. 2.

\section{2) Soil erodibility factor}

Soil erodibility is an important factor for evaluating soil erosion intensity. It refers to whether soil is prone to erosion or not [35]. The empirical formula is:

$$
\begin{aligned}
& K=\left\{0.2+0.3 \exp \left[0.0256 S A N\left(1-\frac{S I L}{100}\right)\right]\right\}\left(\frac{S I L}{C L A+S I L}\right)^{0.3} \\
& \cdot\left(1.0-\frac{0.25 C}{\exp (3.72-2.95 C}\right) \cdot\left(\frac{0.7 S N 1}{S N 1+\exp (-5.51+22.9 S N 1}\right)
\end{aligned}
$$

...where SAN, SIL, CLA, and C show the content (\%) of sand, silt, clay and organic carbon, respectively; and $S N 1=1-S A N / 100$. The values and the spatial distribution of the soil erodibility factor are calculated and shown in Table 3 and Fig. 3.

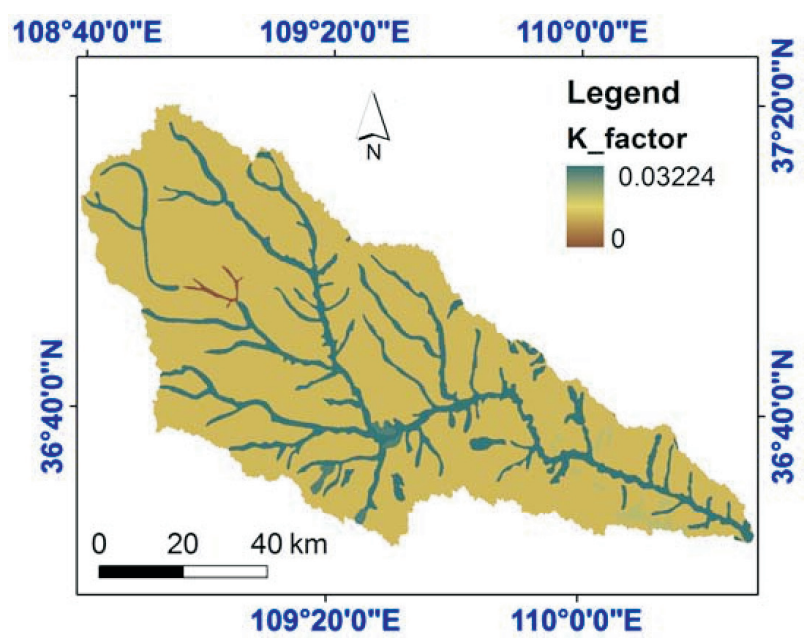

Fig. 3. Soil erodibility factor of the Yanhe River watershed.
3) The slope length and slope gradient factor

Slope length and slope gradient are the basic terrain elements affecting soil erosion. The product of slope length factor $(L)$ and slope gradient factor $(S)$ specifically is the slope length and slope gradient factor $(L S)$, which has also been called the topographic factor. Based on the related literature [36], the slope length and slope gradient factor were calculated by the following equations:

$$
\begin{gathered}
L=\left(\frac{\lambda}{22.13}\right)^{\alpha} \\
\alpha=\frac{\beta}{\beta+1} \\
\beta=\frac{\left(\frac{\sin \theta}{0.0896}\right)}{3.0(\sin \theta)^{0.8}+0.56} \\
S=\left\{\begin{array}{cc}
10.8 \cdot \sin \theta+0.03 \quad \\
16.8 \cdot \sin \theta-0.5 \quad \\
21.91 \cdot \sin \theta-0.96 \quad & \theta \geq 18 \%
\end{array}\right.
\end{gathered}
$$

...where $L$ is the slope length factor; $\lambda$ is the horizontal length of slope, $\mathrm{m} ; \alpha$ is the slope length index; $\beta$ is the parameter; $S$ is the slope gradient factor; and $\theta$ is the slope gradient, \%. The spatial distribution of the $L S$ factor was determined using GIS technology (Fig. 4).

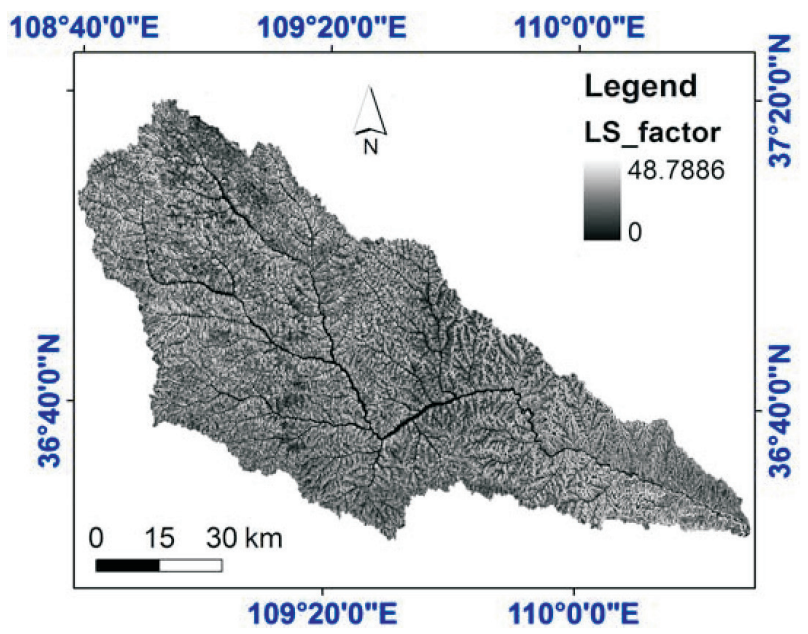

Fig. 4. The slope length and slope gradient factor of the Yanhe River watershed. 
4) The shallow gully erosion factor

Shallow gully erosion (ephemeral gully erosion) is an important type of the slope soil erosion process. It is a transitional type from rill erosion to gully erosion, and it mainly occurs in sloping farmland due also to the gully water catchment. The shallow gully erosion factor $(G)$ reflects effects of shallow gully erosion on watershed erosion and sediment yield. According to Jiang et al. [37], the shallow gully erosion factor is mainly affected by precipitation, the intensity of convergent flow, and soil property. When there is no shallow gully erosion, $G=1$.

$G=1+\left(\alpha-\theta_{c}\right) \cdot\left(1.003\left(R I_{30}\right)^{0.103}-1\right) /\left(30-\theta_{c}\right)$

...where $G$ is the shallow gully erosion factor, $\alpha$ is the surface slope $\left({ }^{\circ}\right), R$ is individual rainfall $(\mathrm{mm})$, and $I_{30}$ is the maximum 30 minutes rain intensity $(\mathrm{mm} / \mathrm{min})$; when the slope is less than $15, G=1$ 。

5) Vegetation cover and management factor

The vegetation cover and management factor $(C)$ reflects comprehensive benefits to prevent soil erosion by natural vegetation and crop cultivation measures of the region. According to the relevant literature [38], the

Table 4. C values of different land use types in the Yanhe River watershed [39].

\begin{tabular}{|c|c|c|c|}
\hline Land use types & C value & Land use types & C value \\
\hline Forest land & 0.09 & $\begin{array}{c}\text { Moderate coverage } \\
\text { grassland }\end{array}$ & 0.18 \\
\hline $\begin{array}{c}\text { Sparse wood } \\
\text { land }\end{array}$ & 0.15 & $\begin{array}{c}\text { Low coverage } \\
\text { grassland }\end{array}$ & 0.32 \\
\hline Shrub land & 0.22 & $\begin{array}{c}\text { Construction and } \\
\text { traffic land }\end{array}$ & 0.20 \\
\hline $\begin{array}{c}\text { High coverage } \\
\text { grassland }\end{array}$ & 0.12 & Water area & 0.00 \\
\hline
\end{tabular}

values and the spatial distribution of the $C$ factor in the Yanhe watershed was determined and shown in Table 4 and Fig. 5.

6) The water and soil conservation factor

The water and soil conservation $(P)$ factor is the ratio of the soil erosion amount of the specific soil and water conservation measures and the soil erosion amount of down slope cultivation without soil and water conservation measures. According to studies of Fu et al. [39], the spatial distribution of $P$ factor was evaluated and shown in Fig. 6.

\section{Results and Discussion}

\section{Spatiotemporal Changes of Soil Erosion} in the Yanhe River Watershed

According to Standards for classification and gradation of soil erosion (SL 190-2007) released by the Ministry of

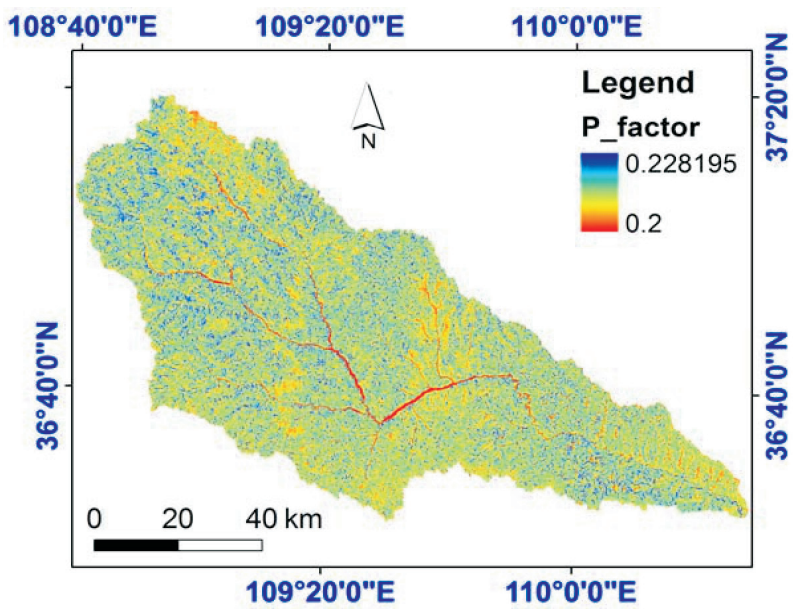

Fig. 6. The water and soil conservation factor of the Yanhe River watershed.
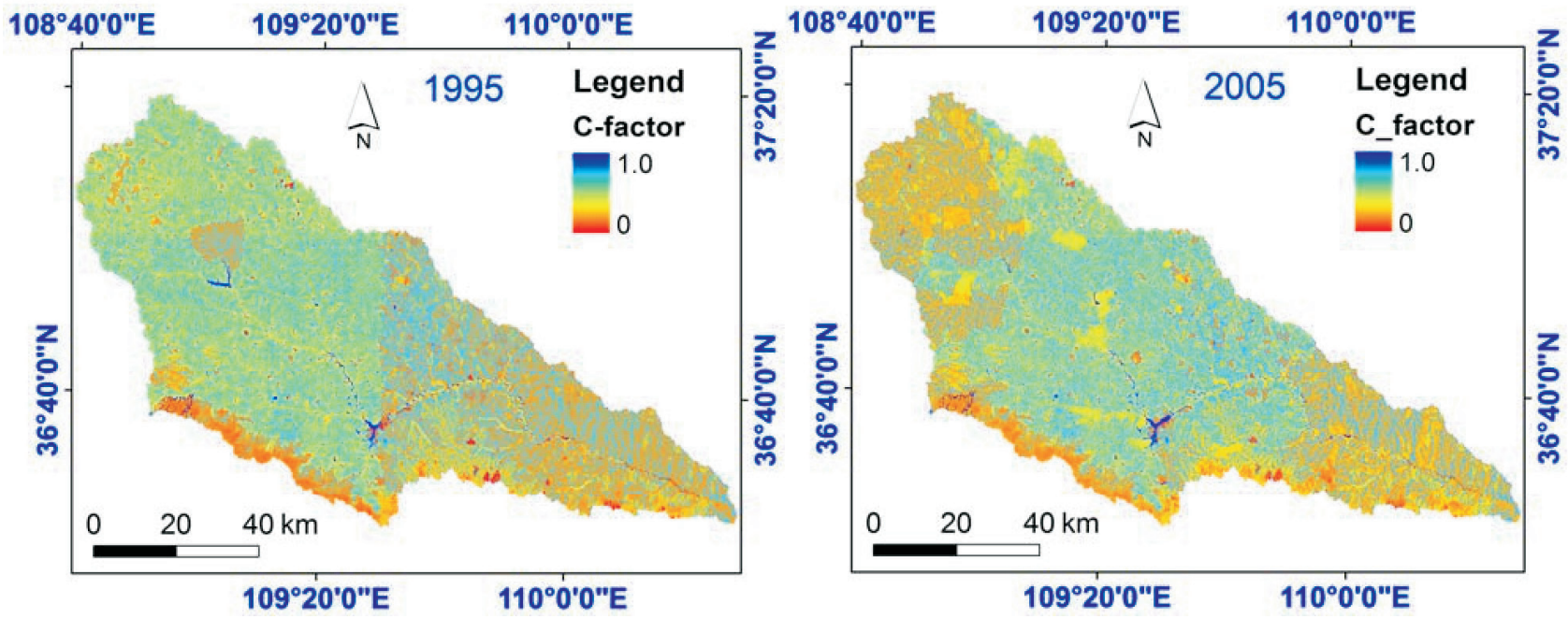

Fig. 5. The vegetation cover and management factor of the Yanhe River watershed from 1985 to 2010. 
Table 5. Statistics for soil erosion classification and gradation of the Yanhe River watershed.

\begin{tabular}{|c|c|c|c|c|c|c|c|c|}
\hline \multirow{2}{*}{ Year } & \multirow{2}{*}{$\begin{array}{l}\text { Erosion } \\
\text { Grading }\end{array}$} & $<5$ & $5 \leq \mathrm{A}<10$ & $10 \leq \mathrm{A}<25$ & $25 \leq \mathrm{A}<50$ & $50 \leq \mathrm{A}<80$ & $80 \leq \mathrm{A}<150$ & $A \geq 150$ \\
\hline & & Micro & Mild & Mild & Moderate & Intensive & Very intensive & Severe \\
\hline 1985 & \multirow{4}{*}{$\begin{array}{c}\text { Percentage } \\
\quad / \%\end{array}$} & 11.463 & 9.578 & 30.854 & 32.216 & 12.884 & 2.900 & 0.105 \\
\hline 1995 & & 15.217 & 13.466 & 36.186 & 30.006 & 4.514 & 0.603 & 0.009 \\
\hline 2005 & & 15.144 & 14.475 & 36.044 & 27.600 & 5.685 & 1.027 & 0.026 \\
\hline 2010 & & 13.017 & 11.887 & 33.067 & 30.284 & 9.551 & 2.136 & 0.058 \\
\hline
\end{tabular}

Note: Standards for Classification and Gradation of Soil Erosion (SL 190-2007) released by the Ministry of Water Resources of the People's Republic of China was published by China Water Power Press in Beijing, 2007.

Water Resources of the People's Republic of China, it can be seen from Fig. 7 that severe erosion occurs mainly on both sides of the main river banks, and soil erosion gradation has large spatial variability. The overall soil erosion level in the southeast and central parts of the watershed is higher than that of the northwest, which is mainly because the south and central parts of the watershed have stronger rainfall distribution and more slope farmland distribution, and the average erosion intensity in this study is basically consistent with previous studies [40, 41]. In addition, the spatial variability of topography and soil also affects the distribution of soil erosion. Based on proportion statistics of erosion grade (Table 5), the soil erosion gradations before and after the project of returning farmland in the watershed are both mainly with mild and moderate erosion, which accounts for more than $60 \%$ of
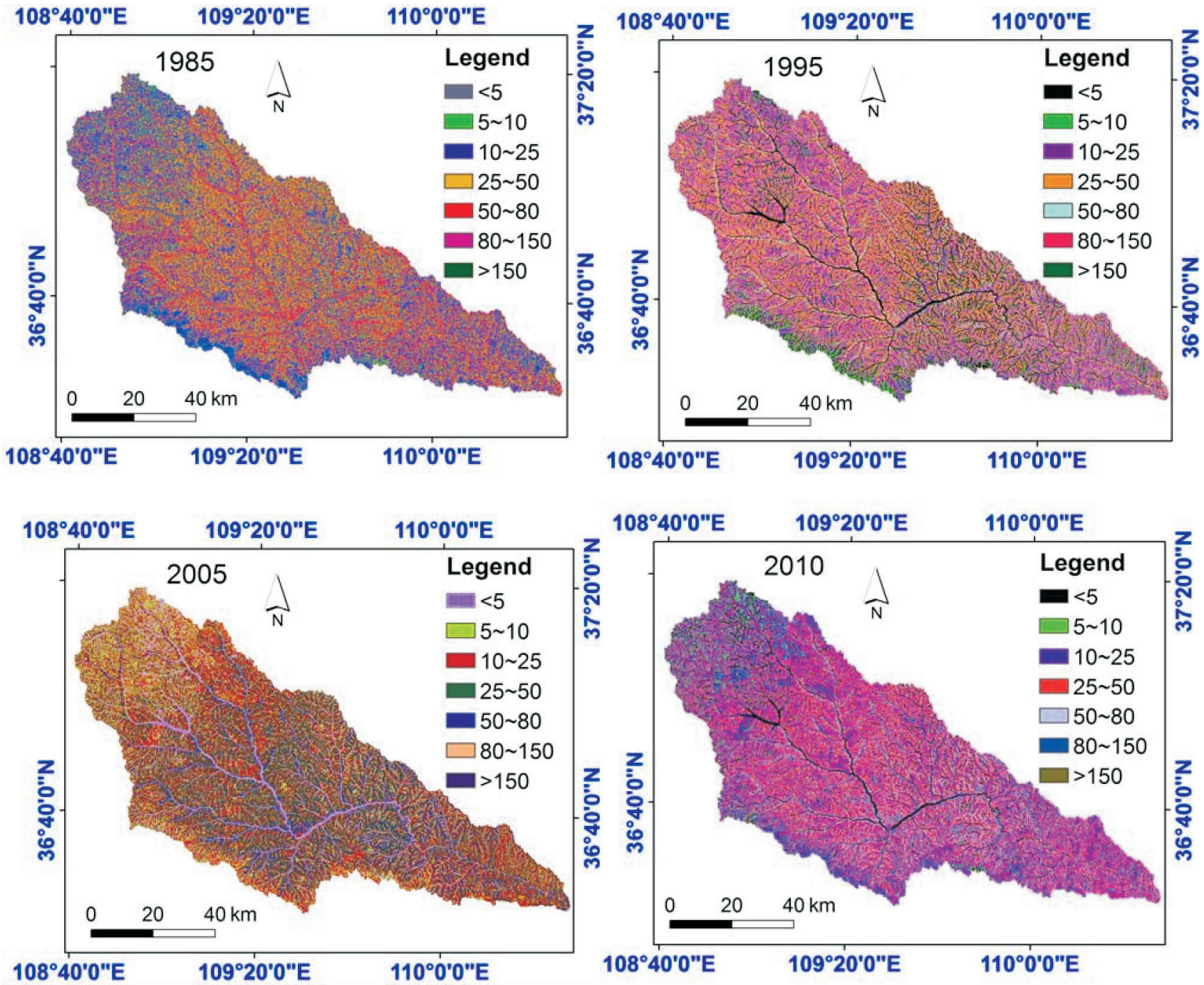

Fig. 7. Spatial distribution of soil erosion classification in the Yanhe River watershed $\left(\mathrm{t} / \mathrm{hm}^{2} . \mathrm{a}\right)$. 
the watershed area. After returning farmland in 1997, the intensive, very intensive, and severe erosion all present a decreasing trend, and the proportion of micro erosion has a slightly increasing tendency. The moderate erosion in 2000 decreased significantly, which is closely related to the implementation of soil and water conservation measures. But in recent years the moderate erosion in the watershed has been a rising trend due to industrialized agriculture and urbanization. The above results are mainly in accordance with studies of $\mathrm{Wu}$ et al. [42] on spatial distribution of soil erosion after returning farmland in a typical watershed of northern Shaanxi Province.

\section{Spatiotemporal Changes of Soil Erosion in Different Sub Watersheds}

Fig. 8 shows that the spatiotemporal changes of soil erosion in different sub watersheds are mainly with mild and moderate erosion. The mild, moderate, and severe erosion in Xichuan sub basin has the largest proportion in all sub basins. It is followed by the Xingzi River sub basin and Yanhe River upstream, the erosion in Panlongchuan sub basin and Yanhe downstream sub basin cannot be ignored in future watershed management planning.

Taking 1995 and 2005 as an example, classification and gradation of soil erosion in different sub basins of the Yanhe River watershed are shown in Tables 6 and 7, respectively. As far as each sub basin is concerned, before returning farmland in 1995, the percentage of mild erosion for $5 \sim 10\left(\mathrm{t} / \mathrm{hm}^{2}\right.$.a) in each sub basin are both approximately $15 \%$, mild gradation of soil erosion for $10 \sim 25\left(\mathrm{t} / \mathrm{hm}^{2} . \mathrm{a}\right)$ in each sub basin all accounts for more than $30 \%$, and moderate gradation of soil erosion for $25 \sim 50\left(\mathrm{t} / \mathrm{hm}^{2}\right.$.a) in each sub basin all accounts for more than $25 \%$, the sum of gradations of mild and moderate erosion accounted for more than $60 \%$ of the total area of the watershed; the most serious region of intensive erosion is YanhewanYangjialing sub basin, which accounts for $5.29 \%$ of the total sub-basin area. After returning farmland in 2005, the percentage of soil erosion gradation has changed in each sub basin.

Percentages of mild and moderate gradation of soil erosion in each sub basin both have an overall downward trend; the most serious region of intensive erosion is Xichuan subbasin, which accounts for $8.84 \%$ of the total sub-basin area, followed by the Yanhewan-Yangjialing sub basin. Percentages of micro $\left(<5 \mathrm{t} / \mathrm{hm}^{2}\right.$.a) and mild erosion in each sub basin both have an overall upward trend. In short, the soil erosion intensity after returning farmland has a slowing trend compared with the former. The reason can be mainly attributed to changes of local land use distribution in the watershed, since 1997, taking small watershed as a management unit, the soil and water conservation ecological project was carried out in loess hilly and gully region.

\section{Spatiotemporal Changes of Soil Erosion in Different Land Use Types}

Fig. 9 shows spatiotemporal changes of soil erosion in different land use types of the watershed. It can be seen from Fig. 9 that dry land plus low and middle
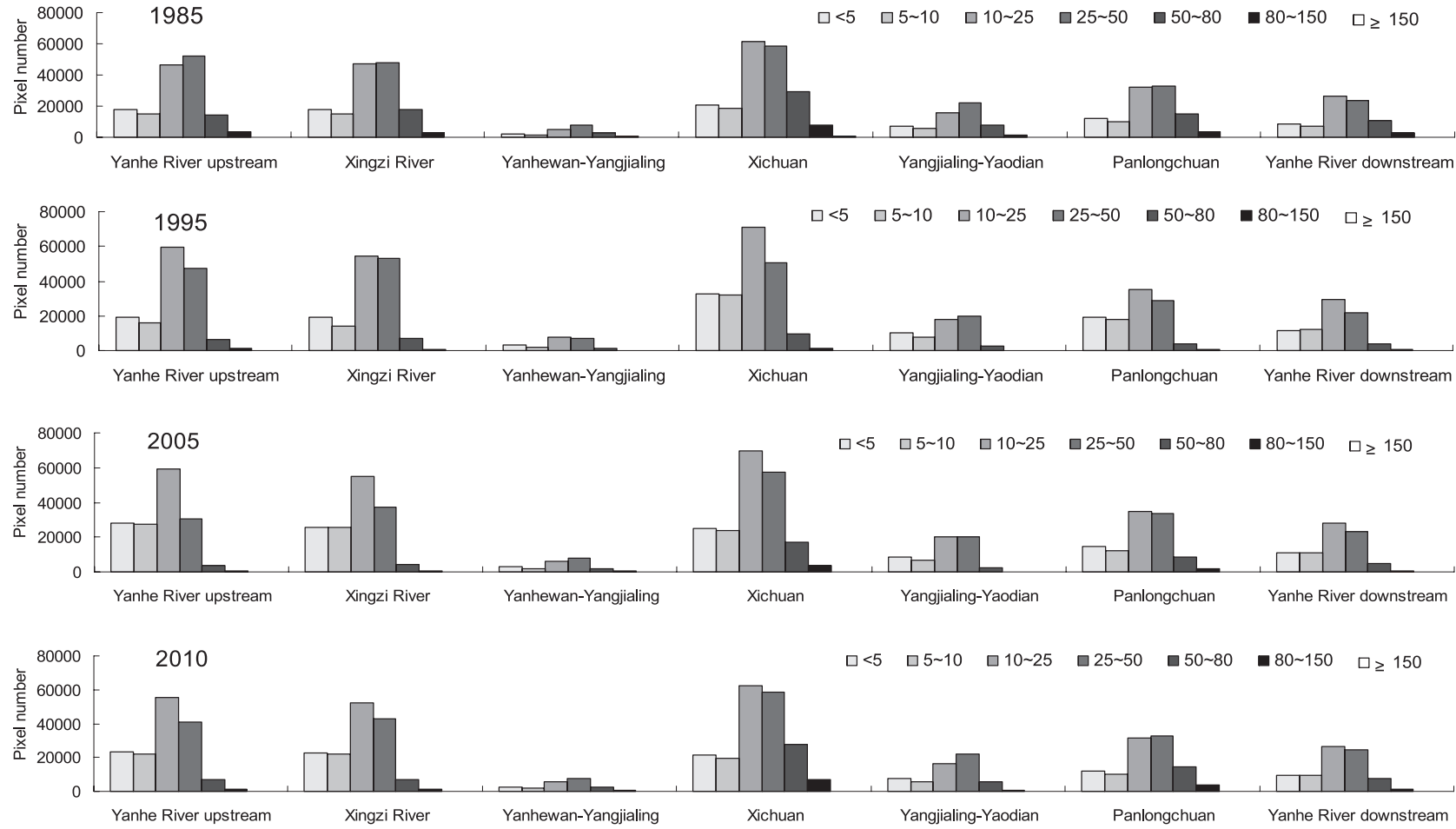

Fig. 8. Classification and gradation of soil erosion and pixel number in different sub basins of the Yanhe River watershed from 1985 to 2010. 
Table 6. Classification and gradation of soil erosion, percentage (\%) of different sub basins of the Yanhe River watershed in 1995.

\begin{tabular}{|c|c|c|c|c|c|c|c|c|}
\hline \multirow{2}{*}{1995} & $\begin{array}{c}\text { Yanhe River } \\
\text { upstream }\end{array}$ & $\begin{array}{c}\text { Xingzi } \\
\text { River }\end{array}$ & \multicolumn{2}{c|}{$\begin{array}{c}\text { Yanhewan- } \\
\text { Yangjialing }\end{array}$} & Xichuan & $\begin{array}{c}\text { Yangjialing- } \\
\text { Yaodian }\end{array}$ & Panlongchuan & $\begin{array}{c}\text { Yanhe River } \\
\text { downstream }\end{array}$ \\
\cline { 2 - 8 } & \multicolumn{7}{|c|}{ Percentage/\% } \\
\hline$<5$ & 13.01 & 12.9 & 14.98 & 16.6 & 17.46 & 18.03 & 14.94 \\
\hline $5 \sim 10$ & 10.86 & 9.52 & 10.4 & 16.17 & 13.1 & 16.92 & 15.55 \\
\hline $10 \sim 25$ & 39.53 & 36.6 & 35.41 & 36.08 & 30.92 & 33.52 & 36.98 \\
\hline $25 \sim 50$ & 31.47 & 35.65 & 32.74 & 25.76 & 33.84 & 27.15 & 27.51 \\
\hline $50 \sim 80$ & 4.45 & 4.74 & 5.29 & 4.74 & 4.21 & 3.94 & 4.48 \\
\hline $80 \sim 150$ & 0.68 & 0.59 & 1.15 & 0.65 & 0.47 & 0.45 & 0.54 \\
\hline$\geq 150$ & 0.00 & 0.00 & 0.03 & 0.02 & 0.00 & 0.01 & 0.01 \\
\hline sum & 100 & 100 & 100 & 100 & 100 & 100 & 100 \\
\hline
\end{tabular}

Table 7. Classification and gradation of soil erosion, percentage (\%) of different sub basins of the Yanhe River watershed in 2005.

\begin{tabular}{|c|c|c|c|c|c|c|c|}
\hline \multirow{2}{*}{2005} & $\begin{array}{c}\text { Yanhe River } \\
\text { upstream }\end{array}$ & $\begin{array}{l}\text { Xingzi } \\
\text { River }\end{array}$ & $\begin{array}{l}\text { Yanhewan- } \\
\text { Yangjialing }\end{array}$ & Xichuan & $\begin{array}{l}\text { Yangjialing- } \\
\text { Yaodian }\end{array}$ & Panlongchuan & $\begin{array}{l}\text { Yanhe River } \\
\text { downstream }\end{array}$ \\
\hline & \multicolumn{7}{|c|}{ Percentage $/ \%$} \\
\hline$<5$ & 18.59 & 17.17 & 13.74 & 12.64 & 14.94 & 13.64 & 13.54 \\
\hline $5 \sim 10$ & 18.32 & 17.43 & 9.93 & 12.21 & 11.63 & 11.79 & 14.12 \\
\hline $10 \sim 25$ & 39.67 & 37.12 & 29.88 & 35.38 & 34.28 & 32.99 & 35.82 \\
\hline $25 \sim 50$ & 20.46 & 25.08 & 36.44 & 29.08 & 34.36 & 31.77 & 29.33 \\
\hline $50 \sim 80$ & 2.62 & 2.87 & 7.77 & 8.84 & 4.27 & 8.08 & 6.24 \\
\hline $80 \sim 150$ & 0.34 & 0.33 & 2.17 & 1.79 & 0.52 & 1.68 & 0.95 \\
\hline$\geq 150$ & 0.00 & 0.00 & 0.08 & 0.06 & 0.00 & 0.05 & 0.11 \\
\hline sum & 100 & 100 & 100 & 100 & 100 & 100 & 100 \\
\hline
\end{tabular}

$\underbrace{19}_{1}$

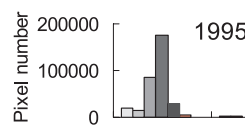

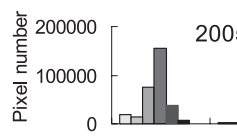

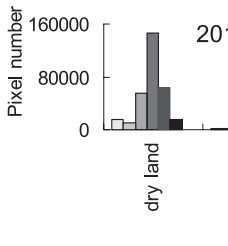

995

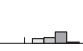

, तh , तh

$\square<5 \square 5 \sim 10 \quad \square$ 10 25 $\square 25 \sim 50 \quad \square 50 \sim 80 \quad \square 80 \sim 150 \quad \square \geq 150$

$\square<5 \square 5 \sim 10 \square 10 \sim 25 \square 25 \sim 50 \quad \square 0 \sim 80 \quad \square 80 \sim 150 \quad \square \geq 150$ , nhth , nll.

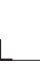

$\square<5 \quad \square 5 \sim 10 \quad \square 10 \sim 25 \square 25 \sim 50 \quad \square 50 \sim 80 \quad \square 80 \sim 150 \quad \square \geq 150$ Th, $\mathrm{H}$ h

$\square<5 \square 5 \sim 10 \quad \square$ 10 25 $\square 25 \sim 50 \quad \square 50 \sim 80 \quad \square 80 \sim 150 \quad \square \geq 150$

Fig. 9. Classification and gradation of soil erosion and pixel number in different land use types of the Yanhe River watershed from 1985 to 2010 . 


\begin{tabular}{|c|c|c|c|c|c|c|c|c|}
\hline 总 & ஸे? & 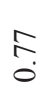 & $\begin{array}{l}\text { ¿ } \\
\stackrel{0}{0}\end{array}$ & $\stackrel{n}{f}$ & $\begin{array}{l}0 \\
\infty \\
\infty \\
i\end{array}$ & $\begin{array}{l}\text { ठे } \\
\text { సे }\end{array}$ & $\stackrel{\bullet}{\rightleftarrows}$ & 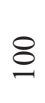 \\
\hline$\stackrel{ت}{\ominus}$ & $\begin{array}{c}m \\
m \\
\infty\end{array}$ & $\stackrel{\infty}{\stackrel{\infty}{n}}$ & $\stackrel{\infty}{i}$ & $\vec{m}$ & $\stackrel{0}{\circ}$ & $\stackrel{0}{0}$ & $\stackrel{8}{\circ}$ & 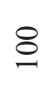 \\
\hline$\frac{\mathbb{z}}{\approx}$ & $\underset{\forall}{\exists}$ & $\begin{array}{l}0 \\
\stackrel{1}{1} \\
\text { I }\end{array}$ & $\begin{array}{l}\infty \\
\infty \\
\varrho\end{array}$ & $\stackrel{m}{6}$ & $\underset{\sim}{\stackrel{f}{r}}$ & $\overline{\widehat{a}}$ & $\stackrel{8}{\circ}$ & 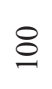 \\
\hline 胥 & $\begin{array}{l}\infty \\
\stackrel{0}{0} \\
i n\end{array}$ & กิ & 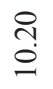 & $\stackrel{n}{\dddot{n}}$ & $\stackrel{\overbrace{}}{\sim}$ & $\stackrel{n}{r}$ & $\stackrel{?}{\stackrel{2}{-}}$ & 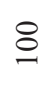 \\
\hline
\end{tabular}

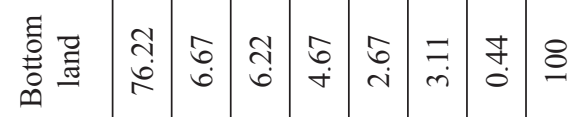

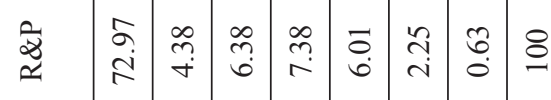

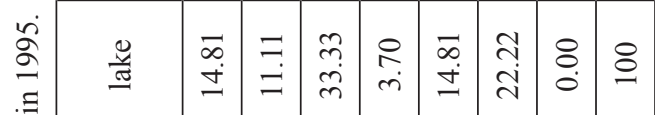

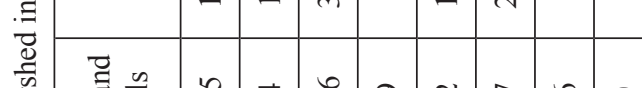

\begin{tabular}{|c|c|c|c|c|c|c|c|c|c|}
\hline 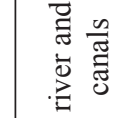 & $\begin{array}{l}n \\
i \\
i n\end{array}$ & $\stackrel{J}{a}$ & $\stackrel{0}{\beth}$ & 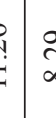 & & & 0 & $\underset{\sim}{\stackrel{\circ}{i}}$ & 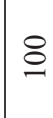 \\
\hline
\end{tabular}

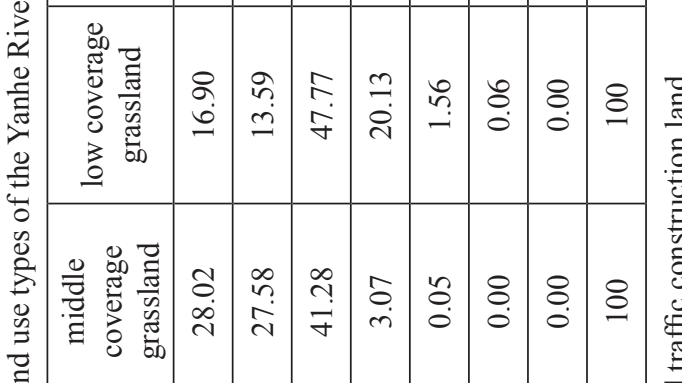

포

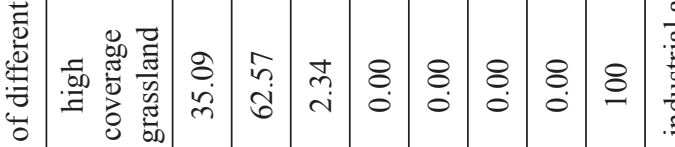

อ

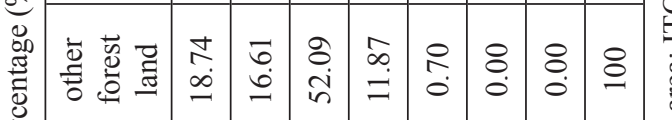

\begin{tabular}{|c|c|c|c|c|c|c|c|c|}
\hline 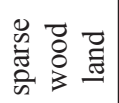 & $\begin{array}{l}\infty \\
\stackrel{\lambda}{ }\end{array}$ & $\begin{array}{l}= \\
\overrightarrow{\dot{q}}\end{array}$ & $\begin{array}{l}\stackrel{a}{+} \\
\infty \\
\stackrel{i}{i}\end{array}$ & $\vec{n}$ & $\begin{array}{l}8 \\
0 \\
0\end{array}$ & 8 & 8 & 8 \\
\hline 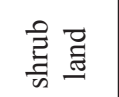 & $\begin{array}{l}\tilde{n} \\
\tilde{n} \\
\hat{n}\end{array}$ & $\begin{array}{l}\stackrel{q}{q} \\
\ddot{v}\end{array}$ & $\begin{array}{l}\tilde{N} \\
\stackrel{n}{n}\end{array}$ & $\begin{array}{l}\hat{N} \\
i\end{array}$ & $\frac{\pi}{0}$ & $\begin{array}{l}8 \\
0 \\
0\end{array}$ & $\begin{array}{l}8 \\
0 \\
0\end{array}$ & 8 \\
\hline 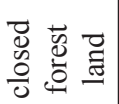 & $\begin{array}{l}\dot{0} \\
+ \\
\infty \\
+ \\
+\end{array}$ & $\begin{array}{c}\stackrel{̊}{\sim} \\
\stackrel{\forall}{\forall}\end{array}$ & $\begin{array}{l}\stackrel{\infty}{\oplus} \\
\stackrel{0}{=}\end{array}$ & 8 & 8 & $\begin{array}{l}8 \\
0 \\
0\end{array}$ & $\begin{array}{l}8 \\
0 \\
0\end{array}$ & 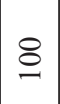 \\
\hline 릉 & $\underset{\text { Oे }}{\tilde{\sigma}}$ & $\begin{array}{l}\exists \\
\overrightarrow{+}\end{array}$ & $\begin{array}{l}n \\
0 \\
i\end{array}$ & $\begin{array}{l}\vec{n} \\
\vec{n}\end{array}$ & $\stackrel{\sim}{a}$ & 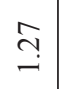 & 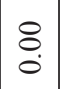 & 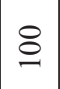 \\
\hline$n$ & $\mathfrak{v}$ & $\begin{array}{l}0 \\
\frac{1}{3} \\
n\end{array}$ & $\begin{array}{l}\hat{\imath} \\
\tilde{c} \\
0\end{array}$ & $\begin{array}{l}0 \\
2 \\
2 \\
i \\
i\end{array}$ & $\begin{array}{l}0 \\
\infty \\
0 \\
0 \\
n\end{array}$ & $\begin{array}{l}\frac{8}{n} \\
\frac{1}{3} \\
\infty\end{array}$ & $\frac{8}{\wedge 1}$ & 志 \\
\hline
\end{tabular}

\begin{tabular}{|c|c|c|c|c|c|c|c|c|}
\hline 总 & $\stackrel{0}{\circ}$ & $\stackrel{+}{0}$ & $\stackrel{\circ}{0}$ & $\begin{array}{l}\stackrel{0}{i} \\
\text { }\end{array}$ & $\begin{array}{l}\infty \\
\stackrel{+}{\sim}\end{array}$ & 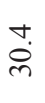 & ఫु & 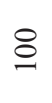 \\
\hline$\underset{\Xi}{\vec{E}}$ & $\vec{\infty}$ & ठ & $\begin{array}{c}\underset{f}{f} \\
\stackrel{i}{*}\end{array}$ & $\underset{i}{\stackrel{\imath}{r}}$ & $\stackrel{8}{\circ}$ & $\stackrel{8}{\circ}$ & $\stackrel{8}{\circ}$ & 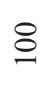 \\
\hline$\underset{\mathbb{2}}{\mathbb{2}}$ & 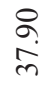 & $\stackrel{?}{=}$ & $\begin{array}{l}2 \\
\stackrel{0}{2}\end{array}$ & $\vec{ָ}$ & $\stackrel{\circ}{+}$ & $\begin{array}{l}\overrightarrow{0} \\
i \operatorname{s}\end{array}$ & $\stackrel{8}{\circ}$ & 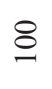 \\
\hline 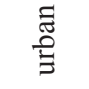 & $\stackrel{-}{\vec{n}}$ & $\stackrel{7}{\sim}$ & oे & $\hat{n}$ & $\underset{\infty}{\tilde{\infty}}$ & $\begin{array}{l}\text { aे } \\
\text {. }\end{array}$ & 芦 & 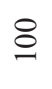 \\
\hline 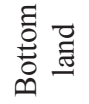 & $\begin{array}{l}\approx \\
\approx \\
2\end{array}$ & $\underset{\sim}{\stackrel{+}{*}}$ & $\begin{array}{l}\infty \\
\infty \\
\end{array}$ & in & 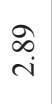 & $\stackrel{m}{m}$ & $\stackrel{0}{\circ}$ & 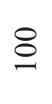 \\
\hline
\end{tabular}

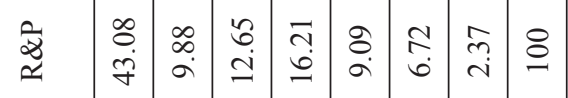

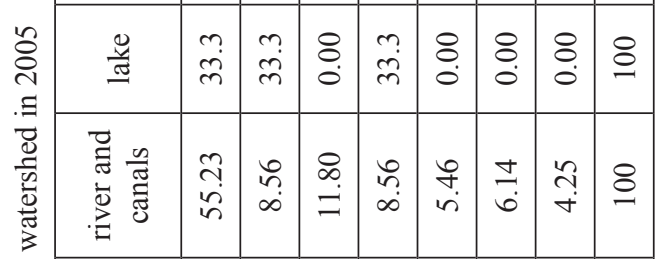

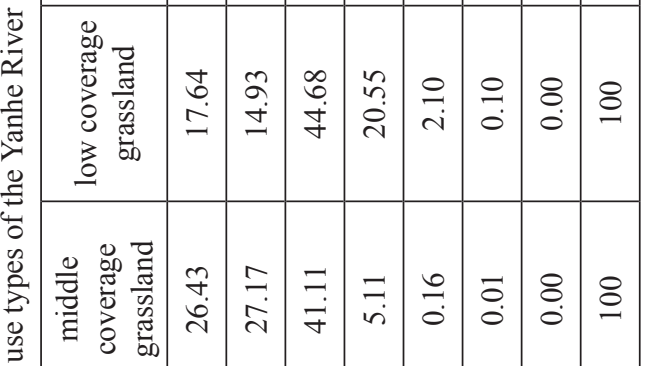

్ㅡㄴ

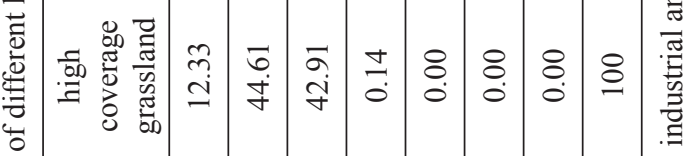

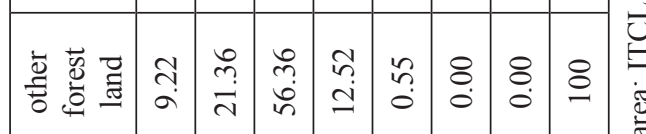

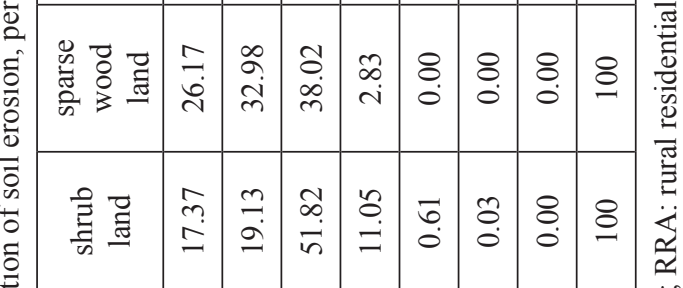

\begin{tabular}{|c|c|c|c|c|c|c|c|c|}
\hline 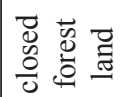 & $\begin{array}{c}\underset{d}{0} \\
\text { m. }\end{array}$ & $\begin{array}{l}\delta \\
\dot{\sigma}\end{array}$ & 苞 & $\stackrel{0}{0}$ & $\stackrel{8}{0}$ & $\stackrel{8}{0}$ & $\stackrel{8}{0}$ & 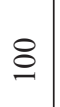 \\
\hline$\vec{\Xi}$ & 苞 & $\begin{array}{l}\stackrel{P}{~} \\
\stackrel{+}{*}\end{array}$ & $\begin{array}{l}\infty \\
\dot{d} \\
\dot{\sim}\end{array}$ & $\begin{array}{c}\tilde{n} \\
\tilde{n} \\
i\end{array}$ & $\stackrel{\text { I }}{\text { I }}$ & $\stackrel{\vec{n}}{i}$ & ठै. & 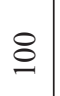 \\
\hline 4 & $\mathscr{v}$ & $\frac{0}{2}$ & $\begin{array}{l}\hat{2} \\
? \\
\text { ?े }\end{array}$ & $\begin{array}{l}8 \\
n \\
2 \\
n\end{array}$ & $\begin{array}{l}\infty \\
\infty \\
0 \\
i \\
n\end{array}$ & $\begin{array}{l}8 \\
\frac{1}{3} \\
\frac{1}{2}\end{array}$ & $\underset{\substack{n \\
\wedge 1}}{2}$ & $\Xi$ \\
\hline
\end{tabular}


coverage grassland are three main critical source areas of soil erosion. From 1985 to 2010 land use changes have affected spatiotemporal distribution of soil erosion.

Tables 8 and 9 show soil erosion gradation and percentage in different land use types of the Yanhe watershed in 1995 and 2005, respectively. As far as each land use is concerned, before returning farmland in 1995, the land use types with a large proportion of erosion mainly include dry land, middle coverage grassland, and low coverage grassland. Where the moderate gradation of soil erosion in dry land accounts for $53.71 \%$ of the total dry land area, the mild gradation of soil erosion in dry land accounts for $25.65 \%$ of the total area, the mild gradation of soil erosion in low coverage grassland is about $47.77 \%$ of the total low coverage grassland area, the mild gradation of soil erosion in the other forest land is about $16.61 \%$ of the total other land area, and the moderate gradation of soil erosion in the other forest land accounts for $11.87 \%$ of the total other forest land area.

After returning to farmland in 2005, percentages of moderate gradation of soil erosion and mild gradation of soil erosion in dry land both have a downward trend in general and decrease by $3.48 \%$ and $0.97 \%$, respectively; the percentage of mild gradation of soil erosion in low coverage grassland decreases by $3.09 \%$; however, percentages of mild gradation of soil erosion and moderate gradation of soil erosion in other forest land increase by $4.75 \%$ and $0.65 \%$, respectively. The above results indicate that changes of soil erosion intensity before and after returning farmland are not only related to land use changes, but also are closely related to the rainfall intensity and rainfall amount. This is also compatible with the early research results by Xie [43].

\section{Conclusions}

This study takes different sub basins and land use types as starting points to track spatiotemporal distributions of soil erosion in the Yanhe River watershed of the hilly and gully region of the Chinese Loess Plateau. Main results can be drawn as follows:

1) The Yanhe River watershed was mainly with mild and moderate erosion before and after the project of returning farmland, and accounts for more than $60 \%$ of the total basin area. After returning to farmland in 1997, the proportion of the intensive, very intensive, and severe erosion slightly decreased, and the micro erosion increased. The severe erosion region mainly occurs on both sides of the main riverbanks, and the overall soil erosion modulus in the southeast and central parts of the watershed is higher than that of the northwest. Spatiotemporal variations of soil erosion in the whole watershed are largely related to spatiotemporal distribution of rainfall erosivity and land use layout.

2) The overall soil erosion gradations in each sub basin of the Yanhe River watershed are mainly with mild and moderate erosion. The mild, moderate, and severe erosion in Xichuan sub basin has the largest proportion in all sub basins, and is followed by the Xingzihe sub basin and Yanhe River upstream sub basin. In addition, the effects of returning to farmland upstream in the Yanhe are remarkable, and the Xingzi River basin has the same good effects as the Yanhe River upstream. While the Xichuan River basin and Yanhe River downstream have only slight changes, the erosion from moderate to severe in Panlongchuan basin is an increasing trend. Therefore, the Panlong River basin needs to further strengthen soil and water conservation measures, and soil erosion in the Yanhe downstream basin cannot be ignored in future watershed management.

3) The cultivated land area decreased after returning farmland in the Yanhe River watershed, taking 1995 and 2010 as an example, the cultivated land reduced by $235.3 \mathrm{~km}^{2}$ accounts for about $3.046 \%$ of the whole basin area, and forest land increased by $277.9 \mathrm{~km}^{2}$, accounting for about $3.597 \%$ of the whole basin area. The overall soil erosion in different land use types of the Yanhe River watershed mainly belongs to dry land, low, and middle coverage grassland, after returning farmland, and the intensive erosion gradation has a decreasing trend. Dry land is the critical source area of soil erosion in the Yanhe River watershed, and the implementation of soil and water conservation measures on dry land in the Yanhe River watershed is a top priority for regional soil erosion prevention and control.

\section{Acknowledgements}

This study was supported by the National Natural Science Foundation of China (No. 51309194), the Special Research Foundation for Young teachers (No. 2452015374), the open foundation of the State Key Laboratory, the Institute of Water and Soil Conservation, the Chinese Academy of Sciences and Ministry of Water Resources (No. K318009902-1417), the Doctoral Fund of the Ministry of Education of China (No. 20130204120034), the Fundamental Research Funds for the Central Universities (No. QN2013047), and the Initial Scientific Research Funds for PhD from Northwest A\&F University (No. 2012BSJJ004).

\section{References}

1. ZHENG F.L., XIAO P.Q. The evolution process of gully erosion and sediment yield in the Loess Plateau. Beijing: Science Press, 2010.

2. TANG K.L. Importance and Urgency of Harnessing the Interlocked Area with Both Water and Wind Erosion in the Loess Plateau. Soil and Water Conservation in China, (11), $11,2000$.

3. TANG K.L., ZHANG K.L. Manmade accelerated erosion and global change on the Loess Plateau. Journal of Water and Soil Conservation, 6 (2), 88, 1992. 
4. HAN F.P., ZHANG X.C., WANG Y.Q., ZHANG X.C. The estimation on loading of non-point source pollution $(\mathrm{N}$, P) in different watersheds of Yellow River. Acta Scientiae Circumstantiae, 26 (11), 1893, 2006.

5. CHEN H.S., SHAOM.A.AReview on the Factors Influencing Flocculation and Deflocculation of Fine Sediment as Nonpoint Source Pollutants. Soil and Environmental Sciences, 9 (4), 322, 2000.

6. QIU L.J., ZHENG F.L., YIN R.S., YU F.Y. Quantification of impacts of precipitation change and human activities on streamflow in the Yanhe River basin. Advances in Climate Change Research, 7 (5), 357, 2011

7. REN Z.P., ZHANG G.H., YANG Q.K. Characteristics of Runoff and Sediment Variation in Yanhe River Basin in Last 50 Years. Journal of China Hydrology, 32 (5), 81, 2012.

8. HU W.Z., WANG S.J., LUO W.J., LIU X.M., BAI X.Y. Land use change and its effects on soil erosion in karst clusterpeak depression region. Chinese Journal of Ecology, 31 (4), 975, 2012.

9. ZHAO D.B., LIANG W., YANG Q.K., LIU A.L. Analysis of dynamic land use changes of past 30 years in the hilly area of Loess Plateau. Bulletin of Soil and Water Conservation, $28(2), 22,2008$

10. XIE H.X., YANG Q.K., LI R., ZHANG X.P., CHENG L., PANG G.W. Quantitative assessment of impacts on decreasing erosion by soil and water conservation measures in Yanhe River Basin. Science of Soil and Water Conservation, 8 (4), 13, 2010.

11. MERRITT W.S., LETCHER R.A., JAKEMAN A.J. A review of erosion and sediment transport models. Environmental Modelling \& Software, 18, 761, 2003.

12. DE VENTE J., POESEN J. Predicting soil erosion and sediment yield at the basin scale: Scale issues and semiquantitative models. Earth-Science Reviews, 71, 95, 2005.

13. KINNELL P.I.A. Event soil loss, runoff and the Universal Soil Loss Equation family of models: A review. Journal of Hydrology, 385, 384, 2010.

14. WILKINSON S.N., DOUGALL C., KINSEYHENDERSON A.E., SEARLE R.D., ELLIS R.J., BARTLEY R. Development of a time-stepping sediment budget model for assessing land use impacts in large river basins. Science of the Total Environment, 468-469, 1210, 2014.

15. WANG G.Q., LI T.J. Basin sediment dynamics model. Beijing: China Water Power Press, 2009.

16. WISCHMEIER, W.H., SMITH, D.D. Predicting rainfall erosion losses-a Guide to Conservation planning. Agriculture Handbook, No. 537. Washington, DC: Agriculture Research Service, US Department of Agriculture, 1978.

17. RENARD, K.G., FOSTER, G.R., WEESIES, G.A., MCCOOL D.K., YODER D.C. Predicting Soil Erosion by Water: A Guide to Conservation Planning with the Revised Universal Soil Loss Equation (RUSLE). Agriculture Handbook, No.703, Washington, DC: Agriculture Research Service, US Department of Agriculture, 1997.

18. 18. DA SILVA R. M., SANTOS C.A.G., DE LIMA SILVA V.C., E SILVA L.P. Erosivity, surface runoff, and soil erosion estimation using GIS-coupled runoff-erosion model in the Mamuaba catchment, Brazil. Environmental Monitoring and Assessment, 185 (11), 8977, 2013.

19. UGUR OZCAN A., ERPUL G., BASARAN M., EMRAH ERDOGAN H. Use of USLE/GIS technology integrated with geostatistics to assess soil erosion risk in different land uses of Indagi Mountatin Pass-CAANKIRI, Turkey. Environ. Geol., 53, 1731, 2008.

20. SONG W.L., ZHANG R.H., GAO Y.F., LU J.X., YANG S.T., QU W., ZHAO D.J. Study on soil erosion intensity classification based on field survey, remote sensing data and CSLE mode. South-to North Water Transfers and Water Science \& Technology, 12 (5), 170, 2014.

21. GAO G.Y., FU B.J., LU Y.H., LIU Y., WANG S., ZHOU J. Coupling the modified SCS-CN and RUSLE models to simulate hydrological effects of restoring vegetation in the Loess Plateau of China. Hydrol Earth Syst Sci 16, 2347, 2012.

22. WU L., LONG T.Y., LIU X., MMEREKI D. Simulation of Soil Loss Processes Based on Rainfall Runoff and the Time Factor of Governance in the Jialing River Watershed, China. Environmental Monitoring and Assessment, 184 (6), 3731, 2012.

23. DABRAL P.P., BAITHURI N., PANDEY A. Soil erosion assessment in a hilly catchment of North Eastern India using USLE, GIS and remote sensing. Water Resour Manage 22, 1783, 2008

24. POLYAKOV V., FARES A., KUBO D., JACOBI J., SMITH C. Evaluation of a non-point source pollution model, AnnAGNPS, in a tropical watershed. Environ Model Soft 22 (11), 1617, 2007.

25. NIGEL R., RUGHOOPUTH S. Mapping of monthly soil erosion risk of mainland Mauritius and its aggregation with delineated basins. Geomorphology 114, 101, 2010.

26. TANG Z.H., CAI Q.G. Review on the studies of Chinese main soil erosion and sediment yield models. Journal of Mountain Science, 20 (4), 466, 2002.

27. LI X.X., GUO Q.X., YANG X.F., LI J.C., YAN R., YAN S.J., ZHAO F.C., LU Q.M. Quantitative study on the soil erosion of Chakou small watershed with the GIS technology and RUSLE model. Journal of Shanxi Agricultural University (Natural Science Edition), 33 (5), 413, 2013.

28. FU B.J., ZHAO W.W., CHEN L.D., LU Y.H., GULINCK H., POESEN J. Assessment of soil erosion at large watershed scale using RUSLE and GIS: a case study in the Loess Plateau of China. Land Degradation \& Development, 16 (1), 73, 2005.

29. ZHENG F.L., WU M., ZHANG Y.B. Ephemeral Gully Development Process at Loess Steep Hillslope. Scientia Geographica Sinica, 26 (4), 438, 2006.

30. VERSTRAETEN G., PROSSER I.P., FOGARTY P. Predicting the spatial patterns of hillslope sediment delivery to river channels in the Murrumbidgee catchment, Australia. Journal of Hydrology, 334, 440, 2007.

31. OGUCHI, T., SAITO, K., KADOMURA, H., GROSSMAN, M. Fluvial geomorphology and paleohydrology in Japan. Geomorphology 39, 3, 2001.

32. LI B.B., ZHENG F.L., LONG D.C., JIANG Z.S. Spatial distribution of soil erosion intensity in Zhifanggou small watershed based on GIS. Scientia Geographica Sinica, 29 (1), 105, 2009.

33. CHENG L.L., ZHAO W.W., ZHANG Y.H., XU H.Y. Effect of spatial distribution of rainfall erosivity on soil loss at catchment scale. Transactions of the CSAE, 25 (12), 69, 2009.

34. ZHANG W.B., XIE Y., LIU B.Y. Rainfall erosivity estimation using daily rainfall amounts. Scientia Geographica Sinica, 22 (6), 705, 2002.

35. LIU B.Y., ZHANG K.L., JIAO J.Y. Soil erodibility and its application in soil erosion prediction. Journal of Natural Resources, 4 (4), 345, 1999.

36. LI T.H., ZHENG L.N. Soil erosion changes in the Yanhe watershed from 2001 to 2010 based on RUSLE model. Journal of Natural Resources, 27 (7), 1164, 2012.

37. JIANG Z.S., ZHENG F.L., WU M. China Water Erosion Prediction Model. Beijing: Science Press, 200-202, 2008. 
38. 38. ZHANG Y., LIU B.Y., SHI P.J., JIANG Z.S. Crop cover factor estimating for soil loss prediction. Acta Ecologica Sinica, 21 (7), 1050, 2001.

39. FU B.J., ZHAO W.W., ZHANG Q.J., LIU Y. The Loess Plateau landscape pattern change and soil erosion. Beijing: Science Press, 2014

40. FU Y.L, ZHANG X.P., CHEN F.J., WAN L., WU Y., LIU G.B. Land Use/Cover Pattern Survey under the Background of Grain for Green Policy Implementation in the Loess Hilly-Gully Region -A Case Study of Majiagou Catchment, Ansai County. Research of Soil and Water Conservation, 17 (6), 81, 2010.
41. CHEN L.D., LV C.H. Study on the scale effect of soil loss and land use in Loess Hilly Region. Beijing: Science Press, 2012.

42. WU Y., ZHANG X.P., CHEN F.J., WAN L., FU Y.L., LIU G.B. Preliminary investigation on soil erosion and spatial distribution after returning farmland in typical watershed of northern Shaanxi Province. Research of Soil and Water Conservation, 17 (4), 29-33, 2010.

43. XIE H.X. Study on the spatio-temporal change of soil loss and on the assessment of impacts on environment of soil and water conservation in Yanhe Basin. Doctoral dissertation, Xian: Shaanxi Normal University, 2008. 